\title{
プロスタグランジンの意義とその臨床応用
}

\begin{abstract}
東島利夫・塩川優一*
Aspects of prostaglandin metabolism and its clinical use The prostaglandin field has advanced rapidly during past several years, and there is a rapidly isncreasing interest in the clinical significance and therapeutic use of prostaglanding for many diseases. The object of this paper is to review the present status of knowledge on the physiological roles, clinical significance and therapeutic uses of prostaglandins.
\end{abstract}

An outline is as follows:

(1) Nomenclature and chemistry of Prostaglandins (PGs).

(2) Ubiquity of PGs.

(3) PG metabolism (arachidonic cascade).

(4) Biologic activiteis and physiological roles of PGs.

a. Central nervous system.

b. Endocrine system.

c. Respiratory system.

d. Cardio-vascular system.

e. Hemostatic system.

f. Digestive system.

g. Renal and reproductive system.

h. eye.

(5) Clinical implication of PGs.

A. Platelet and vascular wall.

B. Renin-angiotensin system.

C. Kallikrein-kinin sytem.

D. Salt and water homeostasis.

(6) Clinical applications of PGs and its analogues.
(1) Gynecologic
(2) Digestive
(3) Cardio-vascular
(4) Peripheral vascular ischemia and thromboembolism
(5) Respiratory
(6) Extracorporeal circulation (7) Ohters

Toshio Tohjima - Yuichi Shiokawa Department of Internal Medicine, Juntendo University School of Medicine

prostaglandin (PG) は, 1934年 Von Euler によっ て発見された脂肪酸の誘導体で, 種々の生理作用を有す る物質として知られていた。この物質は，1957年 Bergstrom と Sjovall によってヒツジ精囊腺から純粋に 分離され, prostanoic acid を基本構造とした不飽和脂 肪酸で, 多くの類縁体を有することが明らかにされ, PG と命名された.

当時, PG はあまりにも多彩な生理作用があり, 化学 的にも不安定なため, その生理的意義が明らかでなかっ た. 1969年, Willis ${ }^{1)}$ は, PG には紅斑や知覚過敏の惹起 作用があり, 炎症の mediator であろうと推定している が，一般医家はPGの重要性にはあまり注目していなか った。しかし, 1971年, Vaneにより，非ステロイド性

\footnotetext{
* 順天堂大学医学部内科学教室
}

抗炎症剤の作用が PG 合成の抑制にあることが明らかに されるに及び，我然，脚光を浴びたのは衆知のとおりで ある.さらに, この数年来の PG 研究の進展は目覚まし く, Hamberg, Samuelsson ら ${ }^{3,4}$ による1974年 $\mathrm{PGG}_{2}, \mathrm{H}_{2}$, 1975年 thromboxane (TX) $\mathrm{A}_{2}$ の発見, 1977年Moncada, Vane らうによる prostacyclin $\left(\mathrm{PGI}_{2}\right)$ の発見, 1979 年 Samuelsson $^{6)}$ による leukotriene (LT) の発見など, 強力 な生理作用を有する PG および PG 関連物質も明らか にされ, 従来, 不明であった種々の生体現象が解明さ れ，PGに対する関心はますます高まっており，臨床医 の立場から PGの意義とその臨床応用について述べてみ たい.

\section{PG の種類と構造}

PG は図 1 に示すごとく, prostanoic acid を基本構造 
(1)

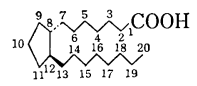

prostanoic acid

(2)

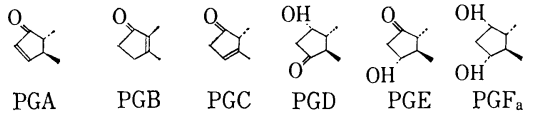



(3)

8,11,14-eicosa $5,8,11,14$-eicosa $5,8,11,14,17$ - eicosa trienoic acid tetraenoic acid pentaenoic acid

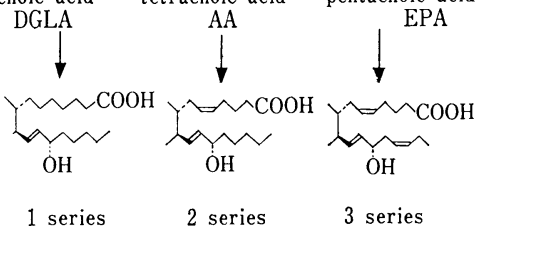

図 1 structures of PGs

(1) thromboxanes

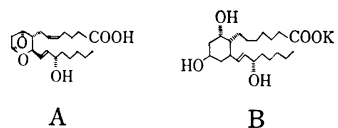

(2) leukotrienes

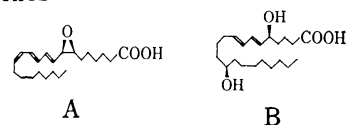

B

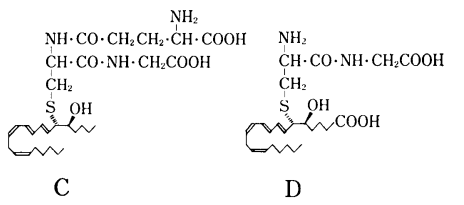

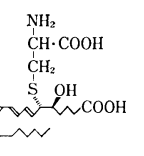

E

\section{図 2}

としており，5員環部分の構造により，A〜 I 群にわけ られる（GとHのみは同じ）。ささらに，側鎖の二重結合 の数に応じて，1,2,3の化合物がある. PG の前駆物質 は，リン脂質由来の bishomo- $\gamma$-linolenic acid (DHL), arachidonic acid (AA), icosapentaenoic acid (EPA) といった脂肪酸であり, phospholipase $\mathrm{A}_{2}$ や phospholipase C-diglyceridelipase により細胞膜リン脂質から 遊離され，それぞれ I series, II series, III series の PG 群が産生される。PG 関連物質である TX は，図 2 に

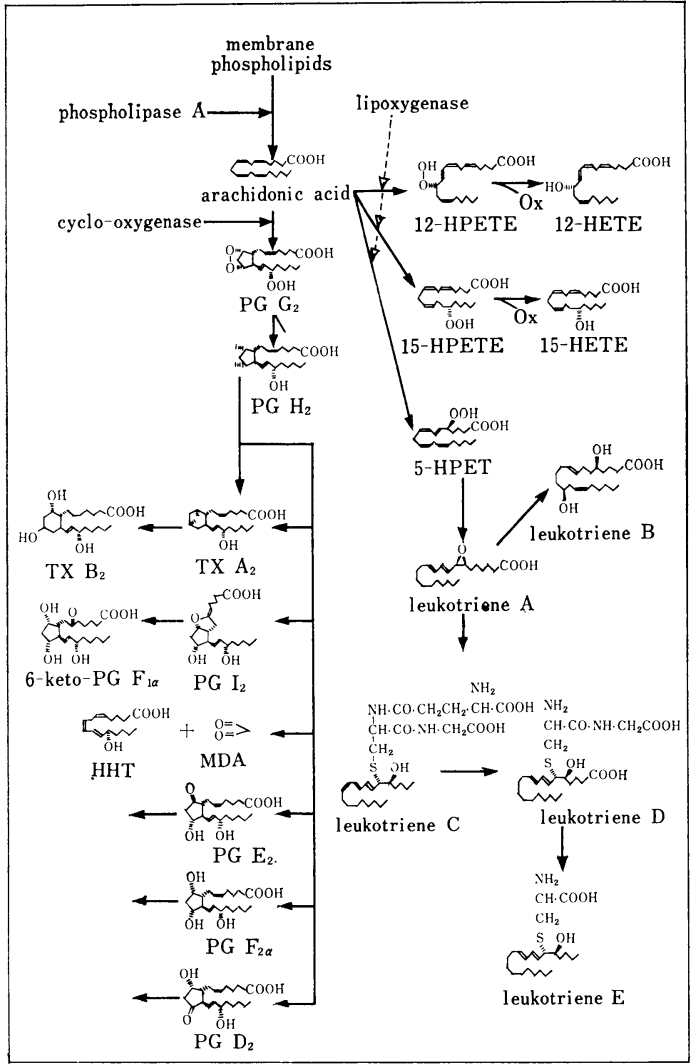

図 3 prostaglandins metobolism (arachidonic acid coscade

示すごとく，トロンバン酸を基本構造としており， $\mathrm{A}$ ， Bの 2 群があり，側鎖の二重結合数によって $1 \sim 3$ の化 合物がある。また，LT は trans，trans， cis の 3 個の 共役二重結合を基本構造とし，A〜 E 群があり，さらに 二重結合の数によって $3,4,5$ の化合物がある.

\section{PG の分布}

PG 代謝を行っている臓器は, サルの PGE-9-Ketoreductase 活性の分布でみると, 表 1 に示すごとく, 脳, 肝, 血液, 腎, 脾, 心, 子宮, 肺などで活発であり, こ の他にも消化管, 目など, ほぼすべての臓器で PG 合成 や代謝が行われていると推定されている.

\section{PG 代謝}

生体内に和ける PG 系のなかで，アラキドン酸を前駆 物質とする II series の PG 代謝がもっとも活発であ るとされており，その主経路を図 3 に示す。すなわち, phosphlipase $\mathrm{A}_{2}, \mathrm{C}$ により, $\mathrm{AA}$ が遊離され，cyclooxygenase と lipoxygenase の二つの経路にわかれる. 炎症に関与している PG 群は, cyclo-oxygenase 系では $\mathrm{PGG}_{2}, \mathrm{TXA}_{2}, \mathrm{PGI}_{2}, \mathrm{E}_{2}, \mathrm{D}_{2}, \mathrm{~F}_{2} \alpha$ である.

一方, lipoxygenase を介するものは，15-HPETE，12- 
表 1 NADPH-and NADH-dependent prosta glandin E 9-ketoreductase activity in different monkey and pigeon tissues

\begin{tabular}{l|r|r}
\hline \multicolumn{1}{c|}{ tissue } & $\begin{array}{c}\text { NADPH } \\
\text { units/mg } \\
\text { protein }\end{array}$ & $\left.\begin{array}{c}\text { NADH } \\
\text { units/mg } \\
\text { protein }\end{array}\right)$ \\
\hline monkey & 1000 & 46 \\
brain & 960 & 100 \\
liver cytoplasmic fraction & 52 & 450 \\
liver microsomal fraction & 770 & 44 \\
blood, formed elements & 480 & 34 \\
kidney & 305 & 41 \\
spleen & 163 & 15 \\
heart & 140 & 33 \\
uterus & 98 & 21 \\
lung & $\mathrm{L}$ \\
\hline
\end{tabular}

(Lee \& Levine, 1974)

表 3 PG 群の生理作用 (2)

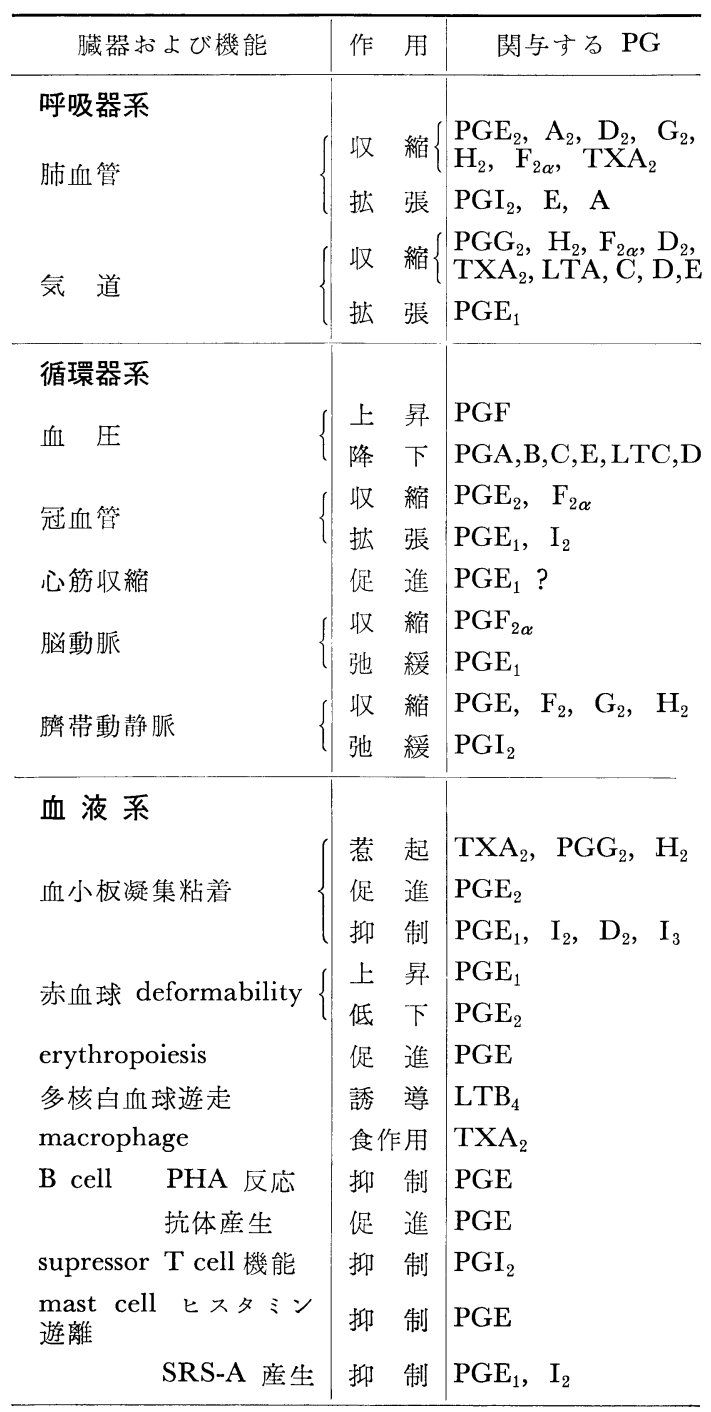

表 2 PG 群の生理作用 (1)

\begin{tabular}{|c|c|c|}
\hline 臟器おょび機能 & 作 用 & 関与する PG \\
\hline 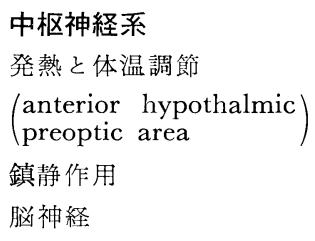 & $\begin{array}{c}\text { 刺 激 } \\
\text { 促 進 } \\
\text { 機能調節 }\end{array}$ & $\begin{array}{l}\text { PGE } \\
\text { PGD }_{2} ?\end{array}$ \\
\hline $\begin{array}{l}\text { 内分泌系 } \\
\text { 視床下部一下垂体 } \\
\left\{\begin{array}{l}\mathrm{LH} / \mathrm{FSH} \cdot \\
\mathrm{ACTH} \\
\mathrm{TSH} \\
\mathrm{GH} \\
\text { Prolactin }\end{array}\right. \\
\text { 甲状腺 } \\
\text { 膵 }\left\{\begin{array}{l}\text { insulin } \\
\text { glucagon }\end{array}\right. \\
\text { 副 腎 } \\
\text { 卵晕 }\left\{\begin{array}{l}\text { progesterone } \\
\text { 卯管運動 }\end{array}\right.\end{array}$ & $\begin{array}{c}\text { 刺 激 } \\
\text { 刺 激 } \\
\text { ? } \\
\text { 刺 激 } \\
\text { 刺 激 } \\
\text { 刺 激 } \\
\text { 抑 制 } \\
\text { 抑 制 } \\
\text { 刺 激 } \\
\text { 刺 激 } \\
\text { ? } \\
\text { 促 進 } \\
\text { 抑 制 }\end{array}$ & $\begin{array}{l}\text { PGE } \\
\quad \mathrm{PGA}_{1}, \mathrm{~B}_{1}, \mathrm{E}_{1}, \mathrm{~F}_{1 \alpha} \\
\quad \text { ? } \\
\mathrm{PGE} \\
\mathrm{PGE}, \mathrm{F}_{2 \alpha} \\
\mathrm{PGE} \\
\mathrm{PGF}_{2 \alpha} \\
\mathrm{PGE}, \mathrm{I}_{2} \\
\mathrm{PGE}, \mathrm{F}_{2 \alpha} \\
\text { PGE } \\
\quad \text { ? } \\
\text { PGF } \\
\text { PGE }\end{array}$ \\
\hline
\end{tabular}

表 4 PG 群の生理作用

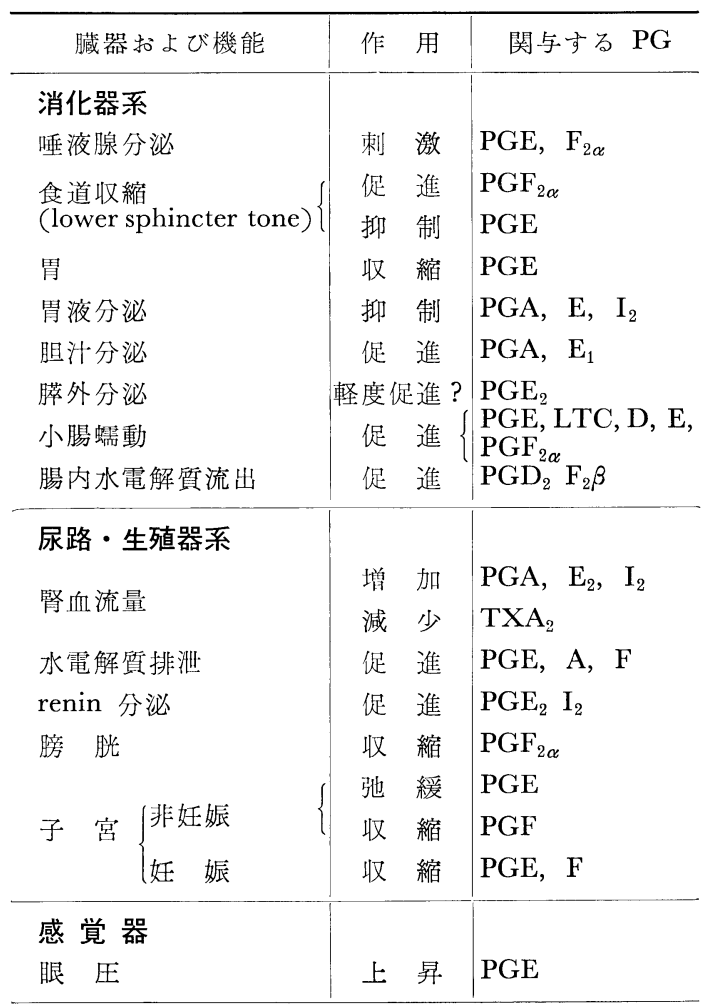




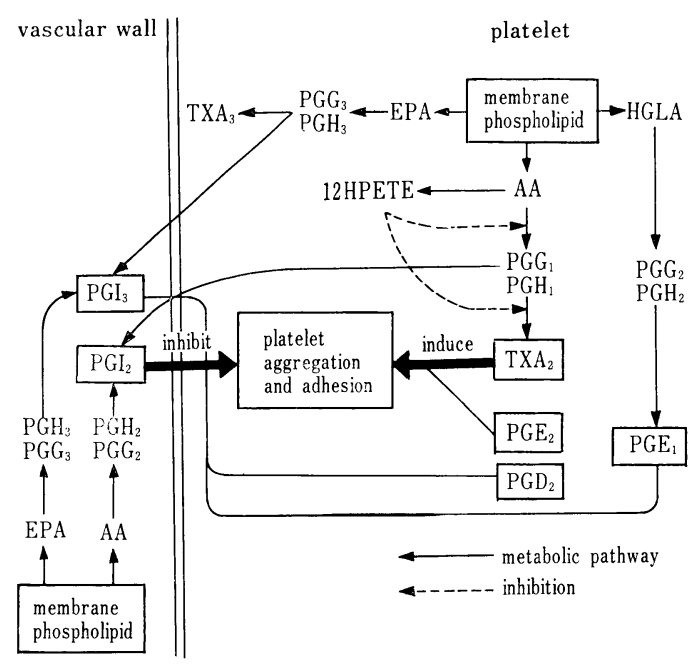

図 4 interaction of platelet function and PG formation between platelet and vascular wall.

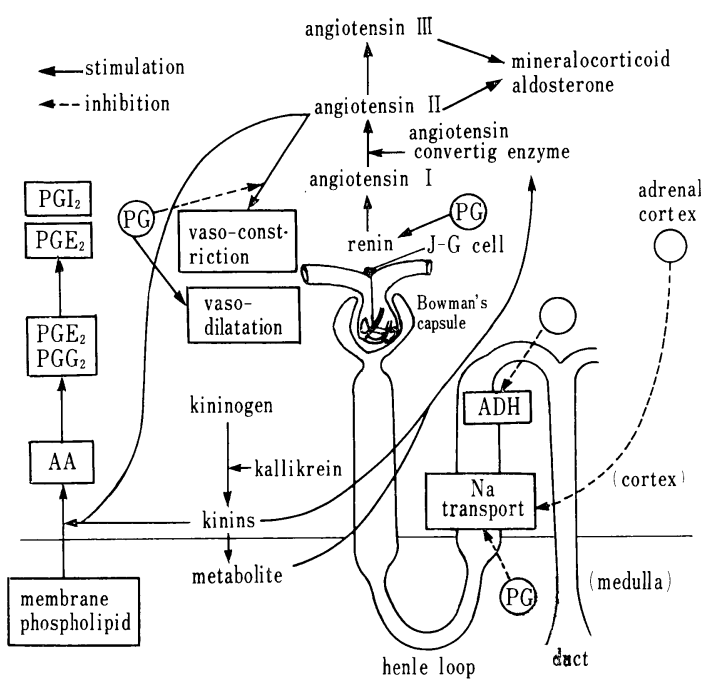

図 5 renal PGs system

HPETE, leukotriene(LT)A, LTB, LTC, LTD, LTE などがある。これらの $\mathrm{PG}$ な, 各蔵器内に貯蔵され，分 泌されるのではなく，必要に応じて，その部位で新たに 産生され，生物学的活性を発揮しており, turn over も 早く， $\mathrm{TXA}_{2}$ を例にとると，30秒で失活する。そして， PGIを除き，肺の一循環で90～95\%が代謝され，さらに は, 腎, 肝においても代謝, 排泄されている。

\section{PG の生理作用}

PG の生理作用については, 生体反応の調節機序の解 明にも熬がるものであり，種々の検討がなされている. すなわち，外因性に PGを作用させると，中枢神経系， 内分泌系, 呼吸器系, 循環器系, 尿路・生殖器系, 支持
組織系, 感覚器系, 血液系といった, ほぼ全身の臓器機 能に種々の変化をきたす，PG の主たる生理作用は表 $2 \sim 4$ に示す.

\section{(1) 中枢神経系}

PGE 群は，発熱中枢の刺激作用と，鎮静作用が認め られている。また，脳には $\mathrm{PGD}_{2}$ が多く含まれており， 脳機能の調節を行っていると推定されている.

\section{(2) 内分泌系}

視床下部一下垂体系では，黄体ホルモン/卵胞刺激ホ ルモン $(\mathrm{LH} / \mathrm{FSH})$, および生長ホルモン $(\mathrm{GH})$ に対し て，PGE は刺激作用がある，ACTH は，I seriesの PG 群により分泌が刺激される。また, prolactin に対し, $\mathrm{PGE}, \mathrm{PGF}_{2 \alpha}$ は刺激作用がある.

甲状腺では，PGE には甲状腺ホルモンの分泌刺激作 用が又られるが， $\mathrm{PGF}_{2 \alpha}$ には，逆に分泌抑制作用があ る。膵では，PGE および $\mathrm{PGI}_{2}$ は耐糖能を悪化させる が，特にPGE $\mathrm{PG}_{1}$ には insulin 分泌抑制作用がある ${ }^{7,8)}$ 。一 方, glucagon 分泌に対して PGE, $\mathrm{PGF}_{2 \alpha}$ は，刺激作用 があり，insulin 分泌の抑制とあいまって，PG には血糖 上昇作用が認められるのであろら。副腎に対しては， PGE は分泌刺激作用がある.

\section{(3) 呼吸器系}

肺血管に対しては, II series の PG 群は, $\mathrm{PGI}_{2}$ を除 きいずれも収縮作用がある。一方， $\mathrm{PGI}_{2}, \mathrm{PGE}_{1}, \mathrm{~A}_{1}$ に は拡張作用がある。気道に対しては，II series の PG 群 および LT 群には，収縮作用がある9)。しかし， $\mathrm{PGE}_{1}$ には，拡張作用がある。

\section{(4) 循環器系}

PGF は，血圧上昇作用，その他の PG 群，および LTC, Dには降下作用がある，冠血管に対しては, $\mathrm{PGE}_{2}$, $\mathrm{F}_{2 \alpha}$ は収縮作用があり, $\mathrm{PGE}_{1}, \mathrm{I}_{2}$ には拡張作用がある。 脳動脈に対しては， $\mathrm{PGF}_{2}$, は収縮作用, $\mathrm{PGE}_{1}$ には弛緩 作用がある。

臍帯動静脈に対しては, $\mathrm{PGE}, \mathrm{F}_{2 \alpha}, \mathrm{G}_{2}, \mathrm{H}_{2}$ には収縮 作用があり， $\mathrm{PGI}_{2}$ には弛緩作用がある。また，腸間膜 血管㦿に対しては， $\mathrm{PGD}_{2}, \mathrm{~F}_{2 \alpha}$ は血流を減少させるが, $\mathrm{PGE}_{2}, \mathrm{I}_{2}$ は増加させる ${ }^{10)}$. 以上の成績は, 血流の調節 を PG 自体が行っている可能性を示している.

\section{（5）血液系}

血小板凝集抢よび粘着に対しては， $\mathrm{TXA}_{2}, \mathrm{PGG}_{2}$, $\mathrm{H}_{2}$ は惹起作用, $\mathrm{PGE}_{2}$ 促進作用, $\mathrm{PGE}_{1}, \mathrm{I}_{2}, \mathrm{D}_{2}, \mathrm{I}_{3}$ に は抑制作用がある。赤血球の deformabilityに対しては, $\mathrm{PGE}_{1}$ は上昇作用, $\mathrm{PGE}_{2}$ には低下作用がある。

さらに，PGは，白血球機能にも影響を及ぼして扣り， 炎症および免疫にも重要な役割を果たしている。すなわ ち, $\mathrm{LTB}_{4}$ は多核白血球の遊走を誘導し ${ }^{11)}, \mathrm{TXA}_{2}$ は macrophage の食作用を促進し ${ }^{12)}$ ，PGE は $\beta$-cell の抗 体産生を促進し ${ }^{13)}$ ， mast cell のヒスタミンの遊離を抑 
表 5

\begin{tabular}{|c|c|c|}
\hline system & indication & PG or PG analogue \\
\hline gynecologic & $\begin{array}{l}\text { induction of labor } \\
\text { artificial abortion } \\
\text { atonic bleeding of uteri }\end{array}$ & $\begin{array}{l}\mathrm{PGE}_{1}, \mathrm{PGE}_{2}, \quad \mathrm{PGF}_{2 \alpha} 0 \mathrm{~N} 0802 \\
\text { 15-methyl-ester } \mathrm{PGE}_{2} \\
\text { 15-methyl-ester } \mathrm{PGF}_{2 \alpha}, 16,16 \text {-dimethyl } \\
\mathrm{PGE}_{2}\end{array}$ \\
\hline digastive & $\begin{array}{l}\text { gastric ulcer } \\
\text { steroid ulcer } \\
\quad \text { (cytoprotection) } \\
\text { ileus } \\
\text { constipation }\end{array}$ & $\begin{array}{l}\mathrm{PGI}_{2} \text {, carbacyclin } \\
\text { 15-methyl (R) } \mathrm{PGE}_{2} \text { methyl ester } \\
\text { 15-methyl (S) } \mathrm{PGE}_{2} \text { methyl ester } \\
\text { 16,16-dimethyl } \mathrm{PGE}_{2} \text { ONO } 481 \\
\text { LTD, PGF } \\
\text { ONO } 1308\end{array}$ \\
\hline cardiovascular & $\begin{array}{l}\text { congenital cardiovascular anomaly (blue } \\
\text { baby) } \\
\text { hypertention } \\
\text { shock }\end{array}$ & $\begin{array}{l}\mathrm{PGE}_{1}, \mathrm{PGE}_{2} \\
\mathrm{PGD}_{2}, \quad \mathrm{PGI}_{2}, \text { LTG. LTD } \\
\mathrm{PGE}_{1}, \quad \mathrm{PGF}_{2 \alpha}\end{array}$ \\
\hline $\begin{array}{l}\text { thromboembolism and peri- } \\
\text { pheral vascular }\end{array}$ & $\begin{array}{l}\text { angina pectoris } \\
\text { myocard infarction } \\
\text { thrombophrebitus } \\
\text { Buerger' sdisease } \\
\text { diabetic gengrene } \\
\text { Raynaud's phenomenon } \\
\text { ischemic skin ulcer } \\
\text { intermittent claudication }\end{array}$ & $\begin{array}{l}\mathrm{PGE}_{1} \mathrm{PGI}_{2} \\
\text { carbocyclin } \\
\text { 6-keto-PGE }\end{array}$ \\
\hline respiratory & asthma bronchiale nasal obstruction & PGI, 20-methyl $\mathrm{PGI}_{2}$ \\
\hline extracorporeal circulation & hemodialysis cardiopulmonary bypass & $\mathrm{PGE}_{1}, \quad \mathrm{PGD}_{2}, \quad \mathrm{PGI}_{2}$ \\
\hline others & $\begin{array}{l}\text { renal transplant rejection } \\
\text { atonic bladder } \\
\text { diabetic neuropathy }\end{array}$ & $\begin{array}{l}\mathrm{PGI}_{2} \text {, carbocyclin } \\
\mathrm{PGF}_{2 \alpha} \\
\mathrm{PGE}_{1}\end{array}$ \\
\hline
\end{tabular}

制する ${ }^{14)}$ 。また， $\mathrm{PGI}_{2}$ は supressor $\mathrm{T}$ cell 機能を抑制 し，SRS-A 産生も抑制するとされている.

(6) 消化器系

PG群は唾液腺, 胆汗および脺液の分泌を促進するが, 胃液の分泌は抑制する ${ }^{15)}$ 。さらに, 食道, 胃を収縮させ, 小腸の蠕動を促進する。

(7) 尿路・生殖器系

腎血流量を $\mathrm{PGA}, \mathrm{E}_{2}, \mathrm{I}_{2}$ は増加させ, $\mathrm{TXA}_{2}$ は減少 させる。

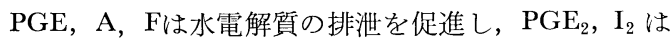
renin 分泌を促進する。 また，膀胱に対しては， $\mathrm{PGF}_{2 \alpha}$ は収縮作用がある。子宮に対しては, 非妊娠時には PGE は弛緩，PGFは収縮作用があるが，妊娠時にはPGE，F ともに収縮作用がある。

(8) 感覚器

PGE には眼圧の上昇作用があることが認められる。

\section{生体内における PG 動態}

すでに述べたごとく，PG には種々の生理作用があり 生体内に拉けるPG 動態とその意義については，この面 での研究がやっと端緒についてばかりであり, 現時点で は，主として外因性に投与された PGの生理作用からの
推測の域をでていない. 特に, 血中に存在している PG およびその代謝産物がいかなる臨床的意義を有している かについては， ほとんど不明に近く，今後，解明される べき分野である，これらの観点から，血中 PGの主要由 来臓器である脈管系に括けるPGの役割について血小板 一血管壁系, 腎 rein-angiotensin 系, kallikrein-kinin系, $\mathrm{Na}$ 利尿系に区分し，最近の知見を含め述べてみたい。

（1）血小板と血管壁の PG 代謝（図 4)

血小板に护ける PG 代謝は, 非凝集時には HGLA 系 の I series の PG 代謝が活発で，血小板凝集を抑制す る $\mathrm{PGE}_{1}$ 代謝が主体である ${ }^{16,17)} . \mathrm{PGE}_{1}$ の血小板凝 集抑制作用は， cAMP の上昇を介する系のほかに，直 接作用もあるとされている。凝集惹起時には， AA 系 の II series の PG 代謝が中心であり, cyclo-oxygenase を介して産生され, 強力な血小板凝集作用のある $\mathrm{TXA}^{z}$ が主役を演じている. 同じ II series の $\mathrm{PGE}_{2}$ ，血小 板凝集促進作用を有しているが，同じ primary PGであ る $\mathrm{PGD}_{2}$ は逆に血小板凝集抑制作用がある。なお， $\mathrm{PGD}_{2}$ の血小板凝集抑制作用は， $\mathrm{PGE}_{1}$ と同じく $\mathrm{cAMP}$ を介するとされているが18), $\mathrm{PGE}_{1}$ にくらべ, cAMP の 上昇は緩徐であり，血小板凝集過程の後期に頂值を示す ことから, feed back 機構により血小板機能を調節して 


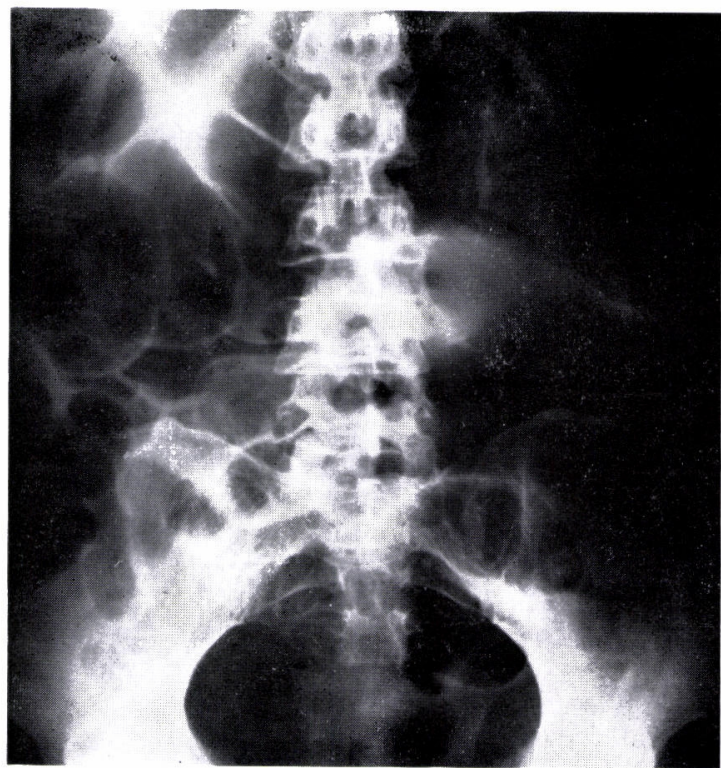

図 6

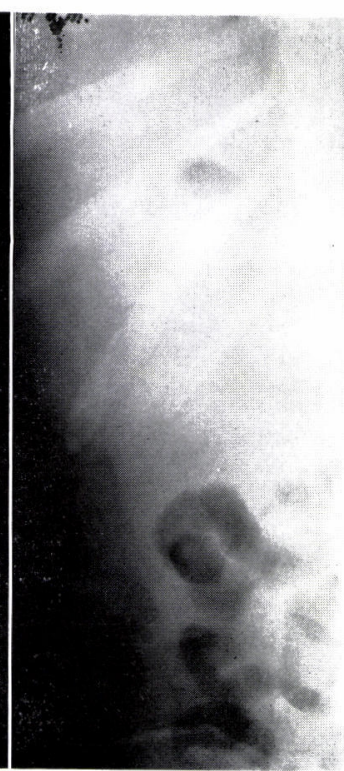

图 7
いる可能性がある。

一方, 血管内皮細胞の PG 代謝は, 強力な血小板凝集 抑制作用と，血管拡張作用を有する II series の PG 系 の一つである $\mathrm{PGI}_{2}$ が主役である。この $\mathrm{PGI}_{2}$ の血小 板凝集抑制機序は， $\mathrm{PGD}_{2}$ とは異なった receptor を 介するとする説と同一の receptor によるとする説があ る $^{19,20)}$.

最近, グリーンランドのエスキモーの心筋梗塞の発生 率が低いのは, サバや夕ラの朋臓に多く含まれる EPA を多く食すため，血小板凝集抑制作用のある III series の $\mathrm{PG}$ 群の一つである $\mathrm{PGI}_{3}$ 産生が増加するためである とされている。なお， $\mathrm{PGI}_{2}, \mathrm{I}_{3}$ の血小板凝集抑制作用 は, $\mathrm{PGE}_{1}, \mathrm{D}_{2}$ と同じく $\mathrm{cAMP}$ の上昇を介していると されている。

一方, 血小板一血管系の PG 代謝には, lipoxygenase 系のものがあり, その一つである 12HPETE は, cyclooxygenase と thromboxane synthetase を阻害するとさ れているが，まだ詳細は不明であり，今後の解明が待た れる分野である。

(2) renin-angiotensin (R-A) 系と PG 代謝(困 5 )

PG \& renin も腎で産生されるが, PGとR-A系は, 腎循環に対し, 正反対に作用しており, 両者のバランス により，腎循環の調節が行われていると推定されてい る。すなわち, $\mathrm{PGE}_{1}, \mathrm{I}_{2}$ の腎動脈注入により腎血流量 が増大するが, angiotensin IIは, 腎血管を収縮させる. また，PG合成阻害剤は， renin 分泌を低下させること， 逆に $\mathrm{PG}$ 前駆物質であるAA, $\mathrm{PGG}_{2}, \mathrm{H}_{2}, \mathrm{I}_{2}, \mathrm{E}_{2}$ といっ た PG および $\mathrm{PG}$ 関連物質を腎に注入すると, renin 分泌が増加すること, angiotensin II は $\mathrm{PGI}_{2}$ 産生を増
加させることなど，PG と R-A 系の関連性が示唆され $ろ^{21)}$.

一方， $\mathrm{PGE}_{2}$ は，腎血管のみを挔張させ，全身の血圧 には影響を与えないが， $\mathrm{PGI}_{2}$ には全身の血圧も低下さ せる作用がある。これは， $\mathrm{PGE}_{2}$ は，肺の一循環で 90〜 95\%で不活性化されるのに対し， $\mathrm{PGI}_{2}$ は，わずかしか不 活性化されないためであるとされている。なお， $\mathrm{PGF}_{2 \alpha}$ は腎血流量に変化を与光ないとされている。

(3) kallikrein-kinin (K-K) 系と PG 代謝（図 6 )

腎皮質の腺性 kallikrein は, 尿細管周囲組織間液に 存在する kininogen に作用し, kinin 群を産生してい る。その一つである bradykinin は, phospholipase $\mathrm{A}_{2}$ 活性を高め, PG 産生を促進することが明らかにされ, bradykinin による腎血管扗張作用は, PG を介する作用 であるとされている，さらに，Na 譻留ホルモンである mineralocorticoid を投与すると, 尿 kallikrein の排泄, 增加とともに PGE の増加をきたすが, kallikrein inhibitor の投与により，PGE 排泄も低下することは，PG と $\mathrm{K}-\mathrm{K}$ 系の密接な関連性を示唆している。

(4) $\mathrm{Na}$ 利尿と PG 代謝 (図 4)

angiotensin II は aldosterone を介して, あるいは, 直接に腎尿細管に作用して，水および $\mathrm{Na}$ 排泄を抑制 しているが， $\mathrm{PGE}_{2}$ には， $\mathrm{Na}$ 利尿作用がある21)。この $\mathrm{PGE}_{2}$ による $\mathrm{Na}$ 利尿作用は， $\mathrm{PGE}_{2}$ と同じく，腎血 流量の増加作用のある $\mathrm{PGI}_{2}$ には, $\mathrm{Na}$ 利尿作用がない ところから, 腎尿細管への直接作用, すなわら, Henle 上行脚㧍よび集合管での Na 輸送抑制作用あるいは, 抗 $\mathrm{ADH}$ 作用によると推定されているが, 副甲状腺ホル モン $(\mathrm{PTH})$ 刺激作用を介する系も否定できない. 


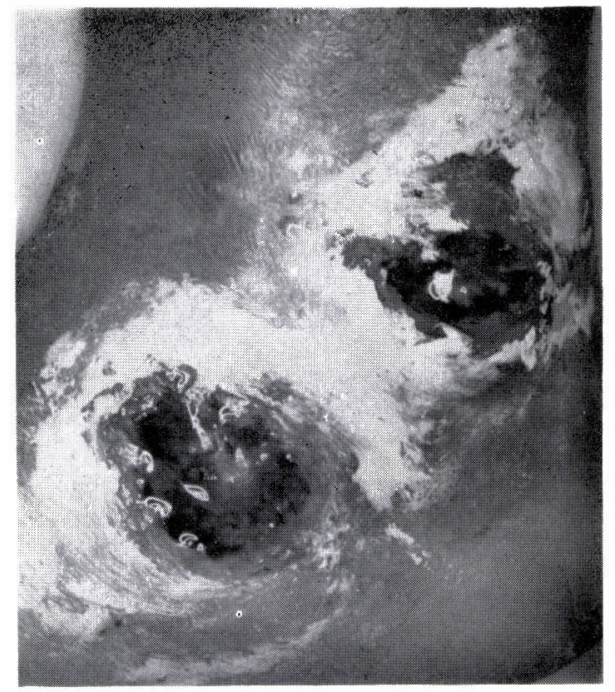

図 8

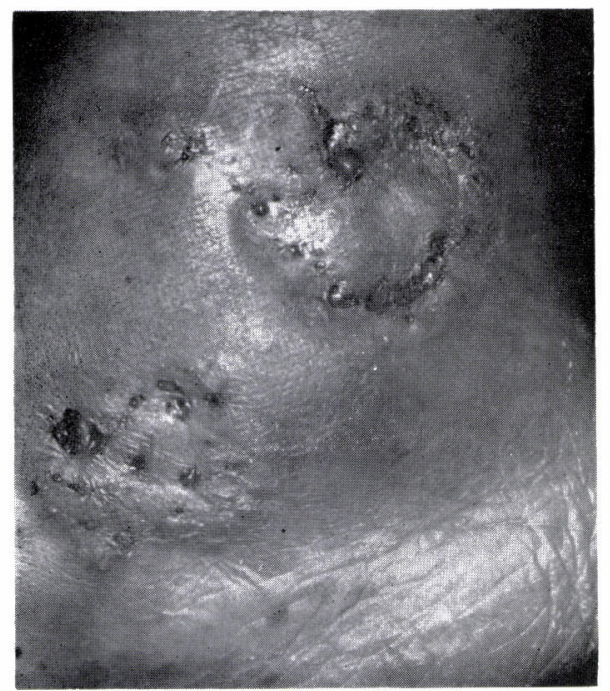

図 9

\section{PG の臨床応用}

PG には多彩な生理作用があるところから，ふるくか ら種々の疾患に対寸る治療薬としての使用が試みられて 扣り, 臨床的にも, 主として, 婦人科領域で用いられて きた。しかし最近では，バジャ一病を中心とした末梢循 環障害の治療にも広く用いられ，われわれは，膠原病患 者の皮原潰瘍，機能性イレウス，レイノ一現象の治療， 糖尿病性壊疽や，神経障害の治療にも用い，その有効性 を確認している。この項では，PG およびその誘導体の 臨床応用について，自験例を含め現況を述べてみたい。

\section{(1) 婦人科領域}

すでに述べたごとく，PG の臨床応用としてもっとも 早く実用化されたのは，婦人科領域である．表 5 に示す ごとく, 分婏誘発, 人口妊娠中絶, 産科の出血, さらに

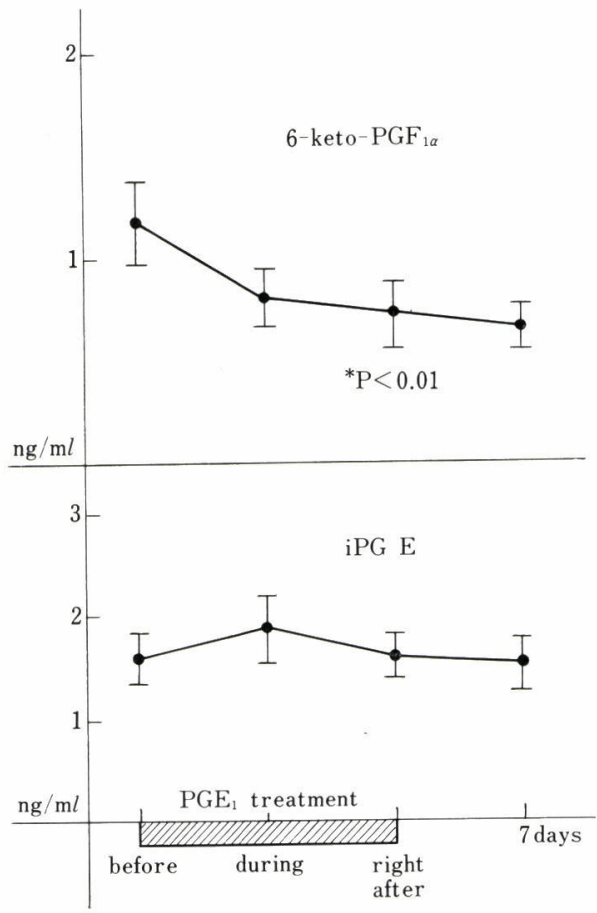

図 10 plasma PG levels before, during and after $\mathrm{PG} \mathrm{E}_{1}$ treatment

は子宮頸部の抾大などに, 腟剂, 子宮腔の卵膜外投与, 静注法, 経口用など種々の製剂が開発され用いられてい る。その種類も $\mathrm{PGE}_{1}, \mathrm{E}_{2}, \mathrm{~F}_{2 \alpha}$ といった primary $\mathrm{PG}$ の ほかに, 15-methyl-ester $\mathrm{PGE}_{2}, \mathrm{~F}_{2 \alpha}, 16$-16-dimethyl $\mathrm{PGE}_{2}$ など生体内で分解されにくい誘導体も開発され， 用いられている。

(2) 消化器領域

消化器系では胃潰瘍やステロイド潰痬の予防および治 療剂として, PGI ${ }_{2}$ や $\mathrm{PGI}_{2} の$ potent stable analogue である carbacyclin がまずあげられる ${ }^{15)}$ ，この carbacyclin は, $\mathrm{PGI}_{2}$ にくらべ胃液分泌抑制作用は $2 \sim 4$ 倍 弱い。また, $\mathrm{PGE}_{2}$ の analogue である15-methyl-PGE $\mathrm{P}_{2}$ methyl ester, 16-16-dimethyl $\mathrm{PGE}_{2}$ などが用いられて いる22). 一方, イレウスや腸管蠕動促進剂として, $\mathrm{PGF}_{2 \alpha}$ ，LTD などが用いられて扮り，われわれも，1 レウスの際に $\mathrm{PGF}_{2 \alpha}$ 療法を行って抢り, その有效性を 確認している。図6 は, mesenteric arteryの血管炎によ り機能性イレウスを起こしたSLE 患者の腹部レ線写真 (臥位) であり，腹部全体に著明なガス像と腸管の払大 が認められる。

図 7 は, $\mathrm{PGF}_{2 \alpha} 2000 \mu \mathrm{g}$ を点滴静注し, 著明な排が ス，排便があり，イレウス症状が軽快した後の腹部レ線 像であり，明らかなガス像の減少と，腸管像の縮少が認 められる。な拈, 便秘の治療剂として ONO 1308 など が用いられている。 


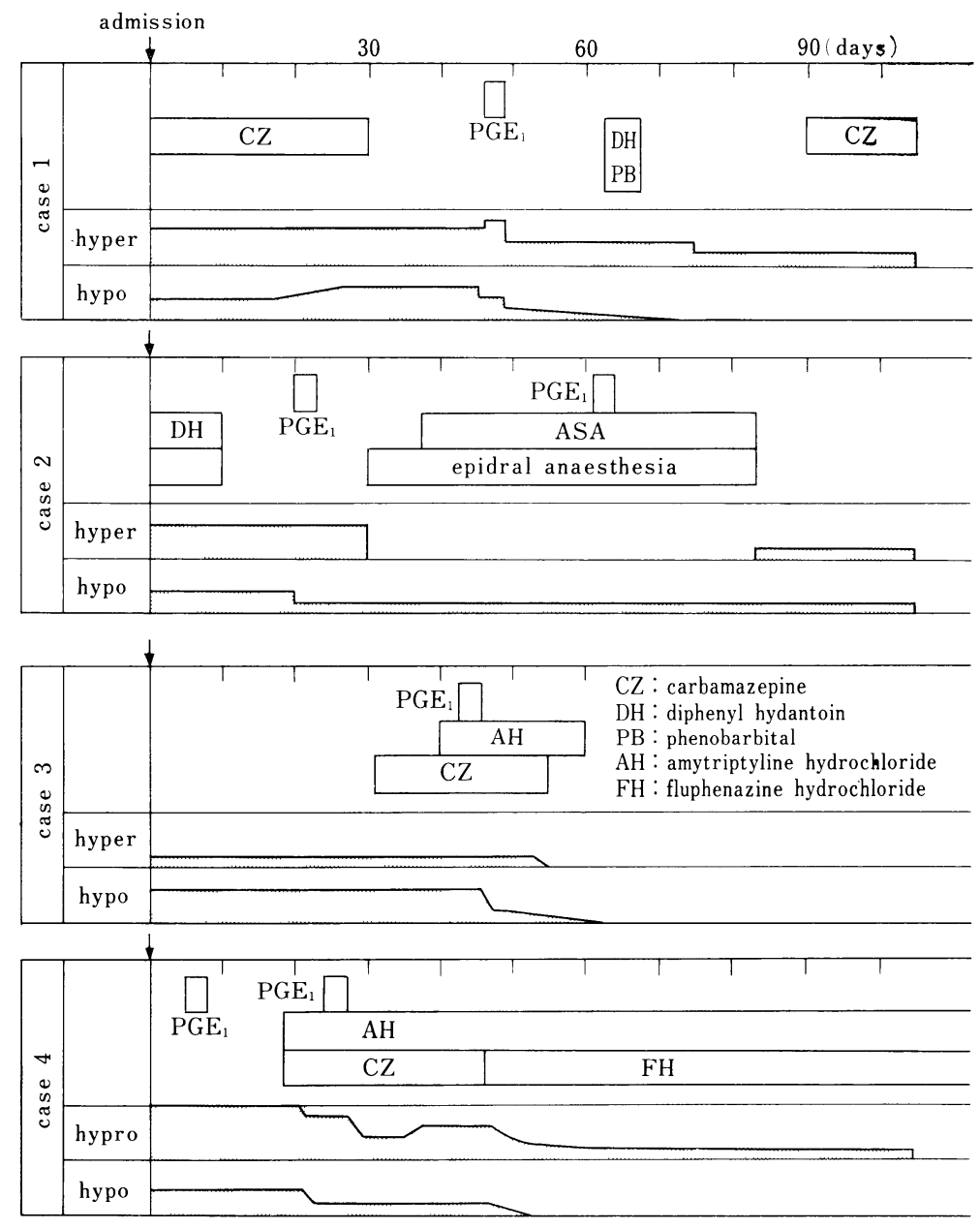

図 11 clinical course of diabetic neuropathy

\section{（3）心脈管系}

新生児期の先天性疾患（すなわち blue baby）では 動脈管の開存が肺血流維持飞必要であり, これらの治療 として， $\mathrm{PGE}_{1} ， \mathrm{E}_{2}$ が用いられている。 また，高血圧症 の治療剤として， $\mathrm{PGD}_{2}, \mathrm{I}_{2}, \mathrm{PGE}_{2}$ analogue, さらに は LTC，LTD などの使用が試みられている。

(4) 種々の血栓症や末梢循環障害

$\mathrm{PGE}_{1}$ やその analogue である OP 1206, $\mathrm{PGI}_{2}$ や $\mathrm{PGI}_{2}$ の biological active metabolite である 6-KetoPGE， $\mathrm{PGI}_{2}$ anaglue である carbocyclin などが用いら れている ${ }^{23)}$.

われわれは，昨年度の本学会において，膠原病に括け る皮䖉潰瘍の治療に $\mathrm{PGE}_{1}$ が有効であることを報告した が24), その後, Clifford ら ${ }^{25)}$ も PSS にみられるレイ, 一現象や指尖潰瘍に $\mathrm{PGE}_{1}$ や $\mathrm{I}_{2}$ 療法の有効性を報告し て打り，炎症性疾患を含屯末梢性循環障害飞対する PG 療法が注目されているところから, 膠原病における $\mathrm{PGE}_{1}$ 療法の成績を簡単に紹介したい，われわれの PG の投

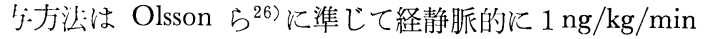
の濃度の $\mathrm{PGE}_{1}$ を 72 時間持続点滴する方法により行な っている.

深部体温計にて测定すると， $\mathrm{PGE}_{1}$ の投与により体温 の上昇が認められ，末梢血流の增大をきたす。図 $8 ， 9$ は左外足部に難治性の皮膚潰瘍をきたした MRA 患者の $\mathrm{PGE}_{1}$ 療法前と治療後 6 週目の写真である。皮㲊潰瘍の 大きさ, 数により治癒までに必要な $\mathrm{PGE}_{1}$ 療法の回数は 異なるが，この症例では， 3 回の $\mathrm{PGE}_{1}$ 療法により, 潰 瘍は添潼ってきている。. $\mathrm{PGE}_{1}$ 療法により, $\mathrm{PGI}_{2}$ の代 謝産物である 6-Keto-PGF 1 $_{1 \alpha}$ の血中 level が図10に示す ごとく，有意に低下するところから，治療前にくらべ, 末梢循環障害に伴う hypoxia が改善されることは間違 いない27).

\section{(5) 呼吸器系}

喘息や鼻道閉塞の治療剤として $\mathrm{PGI}_{2}$ や20-methyl $\mathrm{PGI}_{2}$ の吸入療法が試みられている.

\section{(6) 人口透析や人口心肺}


体外循環路内にみられる凝血現象を防止するために, $\mathrm{PGE}_{1} \mathrm{I}_{2}$ がヘパリンとの併用剂として用いられている. $\mathrm{PGD}_{2}$ は $\mathrm{PGE}_{1}$ の 6 倍の効力があり, 単独でも使用可能 であるとされている。

\section{（7）その他}

腎移植の際の拒絶反応の防止の阻止剂として, $\mathrm{PGI}_{2}$ やその analogue が用いられ, atonic bladder には $\mathrm{PGF}_{2 \alpha}$ が用いられている。 さらに，われわれは，diabetic neuropathy に対し， $\mathrm{PGE}_{1}$ 療法を行っている. 図 11に示すごとく, hyperesthesia に対しては, PGE 1 療法 は無効であるが, hypesthesia に対しては，非常に有効 であった。

\section{おわりに}

以上, $\mathrm{PG}$ の臨床的意義と $\mathrm{PG}$ 療法の現況を自験例も 含め紹介したが，この数年間の PG 研究の進展は目をみ はるばかりであり，PG および PG analogue の臨床応 用もますます盛んになるものと思われる。

\section{文献}

1) Release of histamin, kinin and prostaglandin during carrageenin induced inflammation in the rat. Im: Montegazza, P. and Horton, E.W. (eds.), Prostaglandins, Peptides and Amines. Academic Press, London-New York, 1969, p. 31-38.

2) Vane, J.R.: Inhivition of prostaglandin synthesis as a mechanism of action for aspirin-like drugs. Nature New Biology 231: 232-235, 1971.

3. Hamberg, M., Samuelsson, B.: Prostaglandin endoperoxides. Novel transformation of arachidonic acid in human platelets. Proc. Natl. Acad. Sci. (USA) 71: 3400-3404, 1974.

4) Hamberg, M., Svensson, J., Samuelsson, B.: Thromboxanes: a new group of biologically active compounds derived from prostaglandin endoperoxides. Pro. Nat. Acad. Sci. (USA) 72: 2994-2998, 1975.

5) Moncada, S., Vane, J.R.: The discovery of prostacyclin (PGX): A fresh insight into arachidonic acid metabolism. Proc. of an Intrascience Foundation Conference on Prostaglandins Santa Monica, 1976, p. 1-3.

6) Samuelsson, B., Borgeat, P., Hammastrom. S. et al.: Introduction of nomenclature: Leukotriens. Prostaglandins, 17: 785-787, 1979.

7) Robertson, P., Chen, M.: A role for prostaglandin $\mathrm{E}$ in defective insulin secretion and carbohydrate intolerance in diabetes mellitus. J. Clin. Invest. 60: 747-753, 1977.

8) Szczklik, A., Pieton, R., Sieradzki, J. et al.: The effects of prostacyclin on glycemia and insulin release in Man. Prostaglandins 19(6): 959-968, 1980.

9) Hedquist, P.: Pulmonaty and microvascular effects of the leukotriens. International Sympisium on Leukotrienes and Other Lipoxygenase Products. (Abstract, p 19), Florence, 1981.

10) Chapnick, B.M., Feigen, L.P., Hyman, A.L. et al.: Differential effects of prostaglandins in the mesenteric vascular bed. Am. J. Physiol. 234: H 326-332, 1978.

11) Palmbland, J.: Leukotrien $B_{4}$ is a potent and stereospecific stimulator of neutrophil chemotaxis and adherence. International Symposium on Leukotrienes and Other Lipoxygenase Products. (Absteact, p. 29), Florece, 1981.

12) Goldstein, I.R., Malmsten, C.L., Samuelsson, B. et al.: Prostaglandins, thromboxanes, and polymorphonuclear leukocytes. -Medication and Modulation of Inflammation 2(4): 309-317, 1977.

13) Herscowitz, H.B.: Prostaglandin-induced enhancement of the in vitro anamnestic responce. Prostaglandins 10(1): 87-93, 1975.

14) Platshon, L.F., Kaliner, M.: The effects of the immunologic release of histamine upon human lung cyclic nucleotide levels and prostaglandin generation. J. Clin. Invest. 62: 1113-1121, 1978.

15) Whittle, B.J.R., Steel, G., Roughton-Smith, N.K.: Gastrointestinal action of carbacyclin, a stable mimic of prostacyclin. Communications, J. Pharm. Pharmacol. 32: 603-604, 1980.

16) Lagarde, M., Dechavanne: Basal level of human platelet protsaglandins. $\mathrm{PGE}_{1}$ is more elevated than $\mathrm{PGE}_{2}$. Prostaglandins, 17(5): 685705, 1979.

17）東島利夫，塩川優一，植田伸夫：糖尿病に打ける 血小板凝集能と血小板プロスタグランディン代謝 異常について。医学のあゆみ。117(13)：10811083, 1981.

18) Mills, D.C.B., Macfarlane, D.E.: Stimulation of human platelet adenylate cyclase by prostaglandin $\mathrm{D}_{2}$. Thrombosis Research 5: 401-412, 1974.

19) Miller, O.V., Gorman, R.R.: Evidence for distinct prostaglandin $I_{2}$ and $D_{2}$ receptors in human platelets. J. Pharmacol. Experim. Therapeutics 210(1): 134-140, 1979.

20) Schafer, A.I., Cooper, B., O'Hara, D. et al.: Identification of platelet recepters for prostaglandin $\mathrm{I}_{2}$ and $\mathrm{D}_{2} \mathrm{~J}$. Biol. Chem. 254(8): 2914-2917, 1979.

21) Bolger, P.M., Eisner, G.M., Shea, P.T. et al.: Effects of $\mathrm{PGD}_{2}$ on canine renal function. Nature 267: 628-630, 1977.

22) Gibinski, K., Rybicka, F., Mikos', E. et al.: Double-blind trial on gastroduodenal ulcer healing with prostaglandin $\mathrm{E}_{2}$ analogues. Gut. 18: 636-639, 1977.

23) Quilley, C.P., McGiff, J.C. Lee, W.H. et al.: 6-keto- $\mathrm{PGE}_{1}$ : A possible metabolite of prostacyclin platelet antiaggregatory effects. Hypertension 2: 524-528, 1980. 
24）東島利夫, 上原直樹, 杉本正邦 - 他：膠原病患者 の炎症性皮膚潰疾に対する $\mathrm{PGE}_{1}$ の治療効果。炎 症 1(2)：255-260, 1981.

25) Clifford, P.C.,M artin, M.F.R., Sheddon, E.J. et al.: Treatment of vasospastic disease with prostaglandin $\mathrm{E}_{1}$. Br. Med. J. 281: 1031-1034, 1980.

26) Olsson, A.G., Jogestrand, T.: Effects of prostaglandin $\mathrm{E}_{1}$ in peripheral artery disease. International Conference on Atherosclerosis. edited by Carlson, J.A. et al. Ravan Press, New York, 1978, p. 403-407.
27) Tohjima, T., Uehara, N., Sawada, K. et al. Effect of prostaglandin $\mathrm{E}_{1}$ on inflammatory or ischemic skin ulcer in the patients with peripheral vascular disease. the Intermational Congress on Thrombosis and Haemostasis. (Abstract p 616), Toronto, 1981.

28) Tohjima, T., Sawada, K., Funayama, H. et al.: Treatment of diabetic neuropathies with prostaglandin $\mathrm{E}_{1}$. International Symposium on Diabetic Neuropathy and its Treatment. editated Goto, N. Tokyo, 1981. 